\title{
IN VITRO ANTIPROLIFERATIVE EFFECTS OF SULFORAPHANE ON HUMAN COLON CANCER CELL LINE SW620
}

\author{
Hana Andělová, Emil Rudolf, Miroslav Červinka \\ Charles University in Prague, Faculty of Medicine in Hradec Králové, Czech Republic: Department of Medical Biology \\ and Genetics \\ Summary: The isothiocyanate sulforaphane (SF) has been reported to possess chemopreventive efficiency towards various \\ malignancies including colon cancer. Here, we investigated the antiproliferative and pro-apoptotic effects of SF on colon \\ cancer cell line SW620. We found that SF at concentrations of 10-50 $\mu \mathrm{M}$ inhibits cell viability and proliferation of SW620 \\ cells in a time- and dose-dependent manner, with $\mathrm{IC}_{50}$ being $26 \mu \mathrm{M}(24 \mathrm{~h}), 24.4 \mu \mathrm{M}(48 \mathrm{~h})$ and $18 \mu \mathrm{M}(72 \mathrm{~h})$. Also, in \\ the same cells SF caused DNA damage and chromatin condensation after $24 \mathrm{~h}$ and $48 \mathrm{~h}$ as revealed by phospho- \\ H2A.X western blot analysis and DAPI staining of nuclei. These changes were accompanied by the elevated activity of ca- \\ spase 3, although after $20 \mu \mathrm{M} \mathrm{SF}$ concentration only. Together, these results indicate that SF suppresses growth of human \\ metastacic colonocytes and induces apoptotic cell death.
}

Key words: SW620 cells; Caspase 3, Sulforaphane; Apoptosis; Colon cancer; Proliferation; In vitro

\section{Introduction}

Colorectal cancer is among the most frequent types of cancers in the world and the second most leading cause of cancer-related death in industrialized countries. In the Czech Republic, this malignancy is the second most frequent neoplastic disease following the lung cancer in males and breast cancer in females. It has been reported that the colorectal cancer incidence is inversely related to the consumption of fruits and vegetables. In vitro and in vivo experimental studies have identified phytochemicals (i.e. fibers, carotenoids, vitamins and glucosinolates) as potential dietary chemopreventive agents in the development of cancer of the large intestine. In this respect, vegetables of the Brassicaceae family, in particular those of the Brassica genus (broccoli, cabbage, cauliflower, etc.) have received much attention.

Sulforaphane (SF) $\left[\mathrm{CH}_{3} \mathrm{~S}(\mathrm{O})\left(\mathrm{CH}_{2}\right)_{4}-\mathrm{N}=\mathrm{C}=\mathrm{S}\right]$ is a naturally occurring isothiocyanate found as its glucosinolate precursor in cruciferous vegetables like broccoli. Its chemopreventive effects are well documented both in vitro and in vivo. They include (a) inhibition of phase I cytochrome P450 enzymes, (b) induction of phase II metabolism enzymes, (c) antioxidant functions through increased tissue reduced glutathione (GSH) levels, (d) apoptosis-inducing properties, (e) induction of cell-cycle arrest, (f) anti-inflammatory properties and (g) inhibition of angiogenesis. In addition to these individual mechanisms, their multiple mutual interactions are possible to increase chemopreventive potential of this chemical.
In the present study, we aimed to evaluate the antiproliferative and pro-apoptotic effects of SF on metastatic human colon cancer cell line SW620. We present the evidence that SF decreases cell viability and induces apoptosis in the tested colon cancer cells in vitro.

\section{Material and methods}

\section{Chemicals}

Sulforaphane (SF) (Alexis biochemicals, Axxora Corporation, San Diego, USA)

\section{Cell line treatment}

Human colon cancer cell line SW620 (ATCC No. CCL-227 ${ }^{\mathrm{TM}}$, San Diego, USA) was maintained in Dulbecco's Modified Eagle's Medium (DMEM, Sevapharma, Prague, Czech Republic) supplemented with $10 \%$ foetal bovine serum (FBS) (Gibco, Invitrogen, Carlsbad, USA). Cells were maintained in $37^{\circ} \mathrm{C}$ in humidified atmosphere with $5 \% \mathrm{CO}_{2}$ in an incubator. Passaging took place twice a week upon reaching $90 \%$ cell confluency using $0.05 \%$ EDTA/trypsin.

\section{Neutral Red assay}

Cells were plated in six parallels in 96-well plates (Nunclon, Roskilde, Denmark), left $24 \mathrm{~h}$ in an incubator, and then treated with SF (0-100 $\mu \mathrm{M})$. After 24,48 and $72 \mathrm{~h}$ cells were incubated with neutral red dye dissolved in D-MEM $(3 \mathrm{~h} /$ $37{ }^{\circ} \mathrm{C}, 100 \mu \mathrm{g} / \mathrm{ml}$ final concentration, Sigma-Aldrich, Saint Louis, USA). Cells were then washed with phosphate buf- 
fered saline (PBS), fixed in $\mathrm{CaCl}_{2}(1 \mathrm{~g} / \mathrm{ml}$ in $0,5 \%$ formaldehyde for $15 \mathrm{~min}$ ), lysed in $1 \%$ acetic acid in $50 \%$ ethanol for $15 \mathrm{~min}$ followed by gentle shaking for $15 \mathrm{~min}$ so that complete dissolution was achieved. The absorbance was measured in multiplate reader TECAN SpectraFluor Plus (TECAN Austria GmbH, Gröding, Austria) at $550 \mathrm{~nm}$. Results are expressed as percentage of control values.

\section{Coomasie brilliant blue assay}

Cells were plated in six parallels in 96-well plates (Nunclon, Roskilde, Denmark). Following exposure to SF $(0 \mu \mathrm{M}-100 \mu \mathrm{M})$ for tested time periods cells were fixed in methanol. Next, cells were rinsed with PBS and fixed in a mixture of ethanol and glacial acetic acid (1:50) for 20 min. Following the addition of brilliant blue in ethanol and acetic acid ( $200 \mu \mathrm{l} /$ well), cells were incubated for $1 \mathrm{~h}$. Thereafter, desorption solution ( $0.1 \mathrm{M}$ potassium acetate in $70 \%$ ethanol - $200 \mu \mathrm{l} /$ well) was added and the plates with cells were left on a shaker for $1 \mathrm{~h}$. The absorbance was recorded at $620 \mathrm{~nm}$ with $450 \mathrm{~nm}$ of reference wavelength by a multiplate reader TECAN SpectraFluor Plus (TECAN Austria $\mathrm{GmbH}$, Grödig, Austria). Results are expressed as percentage of control values.

\section{Time-lapse videomicroscopy}

SW620 cells were seeded into a $25 \mathrm{ml}$ plastic tissue-culture flask (Nunclon, Roskilde, Denmark) and left for 24 $\mathrm{h}$ in an incubator with $5 \% \mathrm{CO}_{2}$ at $37^{\circ} \mathrm{C}$. Next day the standard medium was replaced with a medium containing SF ( $0 \mu \mathrm{M}, 5 \mu \mathrm{M}, 10 \mu \mathrm{M}, 20 \mu \mathrm{M}$ and $50 \mu \mathrm{M}$, respectively). The tissue-culture flask was transferred into a $37^{\circ} \mathrm{C}$-heated room where all recordings were performed. Cells were observed continuously over the $72 \mathrm{~h}$ period, using an inverted microscope Olympus IX-71 (Olympus Optical CO, Ltd., Tokyo, Japan) equipped with a long-working-distance condenser, and a $20 \mathrm{X}$ phase contrast lens. For time-lapse recording, the microscope was equipped with a Mitsubishi CCD-100E camera (Mitsubishi Corporation, Tokyo, Japan) and connected to a Mitsubishi video recorder HS-S5600 (Mitsubishi Corporation, Tokyo, Japan). The recording was performed in a 480 mode, with a slowing factor of 160 and it continued for $72 \mathrm{~h}$, with a subsequent video analysis. The recorded sequences were converted to digitized format, processed by the software Adobe Premiere 6.0, and analyzed.

\section{Western Blot analysis}

Cells were seeded into $75 \mathrm{ml}$ flasks (Nunclon, Roskilde, Denmark) and cultivated for $24 \mathrm{~h}$. Following SF exposure, treated and control cells were harvested at different time intervals, washed with PBS and lysed. Whole cell extracts were prepared in $500 \mu \mathrm{l}$ of lysis buffer $(137 \mathrm{mM} \mathrm{NaCl}, 10 \%$ glycerol, $1 \%$ n-octyl- $\beta$-D-glucopyranoside, $50 \mathrm{mM} \mathrm{NaF}$, $20 \mathrm{mM}$ Tris - pH 8, $1 \mathrm{mM}, \mathrm{Na}_{3} \mathrm{VO}_{4}$, Complete TMMini). The lysates were boiled for $5 \mathrm{~min} / 95^{\circ} \mathrm{C}$ in SDS sample buffer (Tris-HCl pH 6.81, 2-mercaptoethanol, 10 \% glycerol,
SDS, $0.1 \%$ bromphenol blue) and thereafter they were loaded onto a $12 \% \mathrm{SDS} /$ polyacrylamide gel. Each lysate contained equal amount of protein $(20 \mu \mathrm{g})$ as determined by Bicinchoninic acid assay (Sigma-Aldrich, Saint Louis, USA). After electrophoresis, proteins were transferred to a polyvinylidene fluoride membrane $(100 \mathrm{~V}, 60 \mathrm{~min})$ and incubated at $25^{\circ} \mathrm{C}$ for $1.5 \mathrm{~h}$ with a solution containing $5 \%$ non-fat dry milk, $10 \mathrm{mM}$ Tris- $\mathrm{HCl}$ (pH 8.0), $150 \mathrm{mM} \mathrm{NaCl}$, and $0.1 \%$ Tween 20 (TBST). Membranes were incubated with primary antibodies (monoclonal mouse phosphoH2A.X, 1:100, rabbit polyclonal $\beta$-actin, 1:100, Cell Signalling Technology, Inc., Danvers, USA) at $4^{\circ} \mathrm{C}$ overnight followed by five $6 \mathrm{~min}$ washes in TBST. Next, the blots were incubated with secondary peroxidase-conjugated antibodies ( $1: 1000,1 \mathrm{~h}, 25^{\circ} \mathrm{C}$, Dako A/S, Glostrum, Denmark), washed with TBST and the signal was developed with a chemiluminescence (ECL) detection kit (Boehringer Mannheim-Roche, Basel, Switzerland). Results were photographed by LightBis system (DNR Bio-Imaging Systems, Jerusalem, Israel). Relative quantifications of phospohorylated H2A.X and $\beta$-actin expression were measured using GelQuant Ver 2.7 software (DNR Bio-Imaging Systems, Jerusalem, Israel).

\section{Fluorescence microscopy}

SW620 cells were grown on coverslips in an incubator with $5 \% \mathrm{CO}_{2}$ at $37^{\circ} \mathrm{C}$ for $24 \mathrm{~h}$. After $24 \mathrm{~h}$, the standard medium was exchanged for a medium with tested concentrations of SF and cells were treated for different time intervals. After the treatment, the cells on coverslips were washed with cold PBS, fixed in $3 \%$ paraformaldehyde, labeled with DAPI $(1 \mu \mathrm{g} / \mathrm{ml})$ (Sigma-Aldrich, Saint Louis, USA) for 5 min and mounted into Prolong Gold ${ }^{\circledR}$ medium (Molecular Probes, Inc. Eugene, USA). The cells were examined under a fluorescence microscope Nikon Eclipse E 400 (excitation filter 330-380 nm and emission filter $420 \mathrm{~nm}$ ) equipped with the digital color matrix camera COOL 1300 (VDS, Vosskühler, Germany). Photographs were taken using the software Nikon Nis Elements (LIM, Prague, Czech Republic) and analyzed. Experiments were done in triplicates.

\section{Activity of caspase 3}

SW620 were seeded into $75 \mathrm{ml}$ flasks (Nunclon, Roskilde, Denmark) and left for $24 \mathrm{~h}$ in an incubator with $5 \% \mathrm{CO}_{2}$ at $37{ }^{\circ} \mathrm{C}$. Next day the standard medium was replaced with a medium containing SF $(0 \mu \mathrm{M}, 5 \mu \mathrm{M}, 10 \mu \mathrm{M}$, $20 \mu \mathrm{M}$ and $50 \mu \mathrm{M}$, respectively). Cells were grown under these conditions for up to $72 \mathrm{~h}$. Caspase 3 Assay Kit, Fluorimetric (Sigma - Aldrich, Saint Louis, USA) was used according to the manufacturer's instructions. Activity of caspase 3 in cell lysates was measured in multiplate reader TECAN SpectraFluor Plus (TECAN Austria GmbH, Gröding, Austria) at 360/465 nm filter combination. The results were expressed as $\mathrm{nmol} / \mathrm{min} / \mathrm{mg}$ of protein. 


\section{Statistics}

Statistical analysis was carried out with a statistical program GraphPad Prism 4.0 (GraphPad Software, Inc. San Diego, USA) using the one-way Anova test with Dunnett's post test for multiple comparisons. Results were compared with control samples, and means were considered significant if $\mathrm{P}<0.05$.

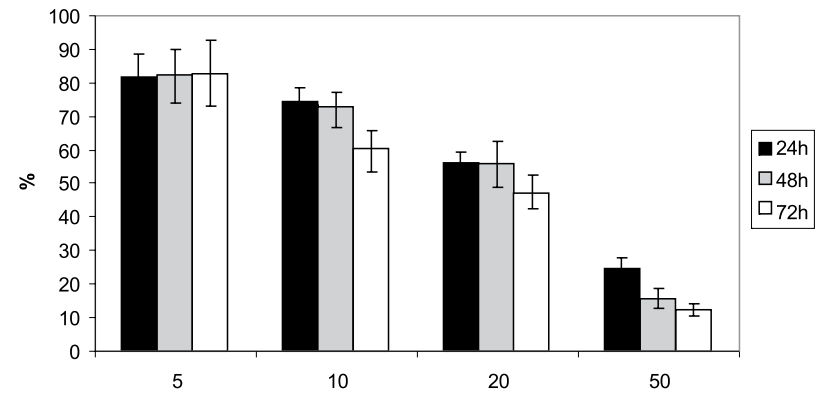

a)

Sulforaphane $(\mu \mathrm{M})$

\section{Results}

SF decreases viability and proliferation of SW620 human colon cancer cells

$\mathrm{SF}$ at a tested concentration range $(0-100 \mu \mathrm{M})$ produced time- and dose-dependent inhibition of SW620 cell viability and proliferation as measured by Neutral red up-

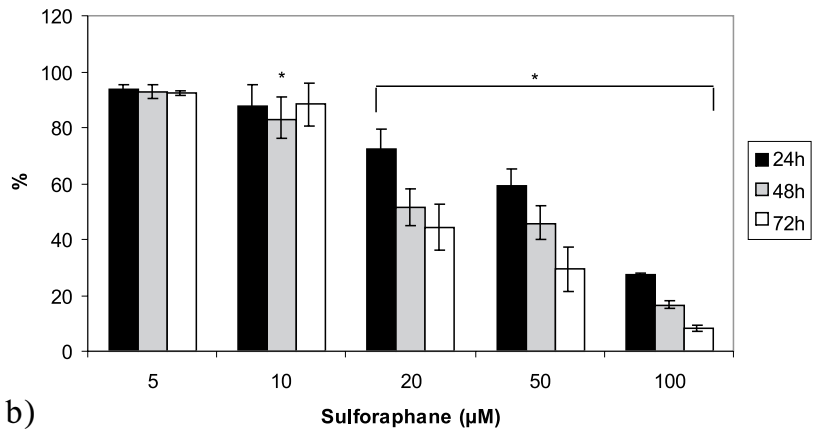

Fig. 1: Effects of sulforaphane (SF) on cell viability and proliferation. SW620 cells were treated with SF concentrations $(0-100 \mu \mathrm{M})$ for up to $72 \mathrm{~h}$. (a) Neutral red uptake assay, all results are significantly different from control, (b) Coomasie brilliant blue assay. Results are expressed as percentage of control cultures. Values represent the mean \pm SD of three independent experiments. ${ }^{*} \mathrm{P} \leq 0.05$, significantly different from control with one way-Anova test and Dunnett's post test for multiple comparisons.

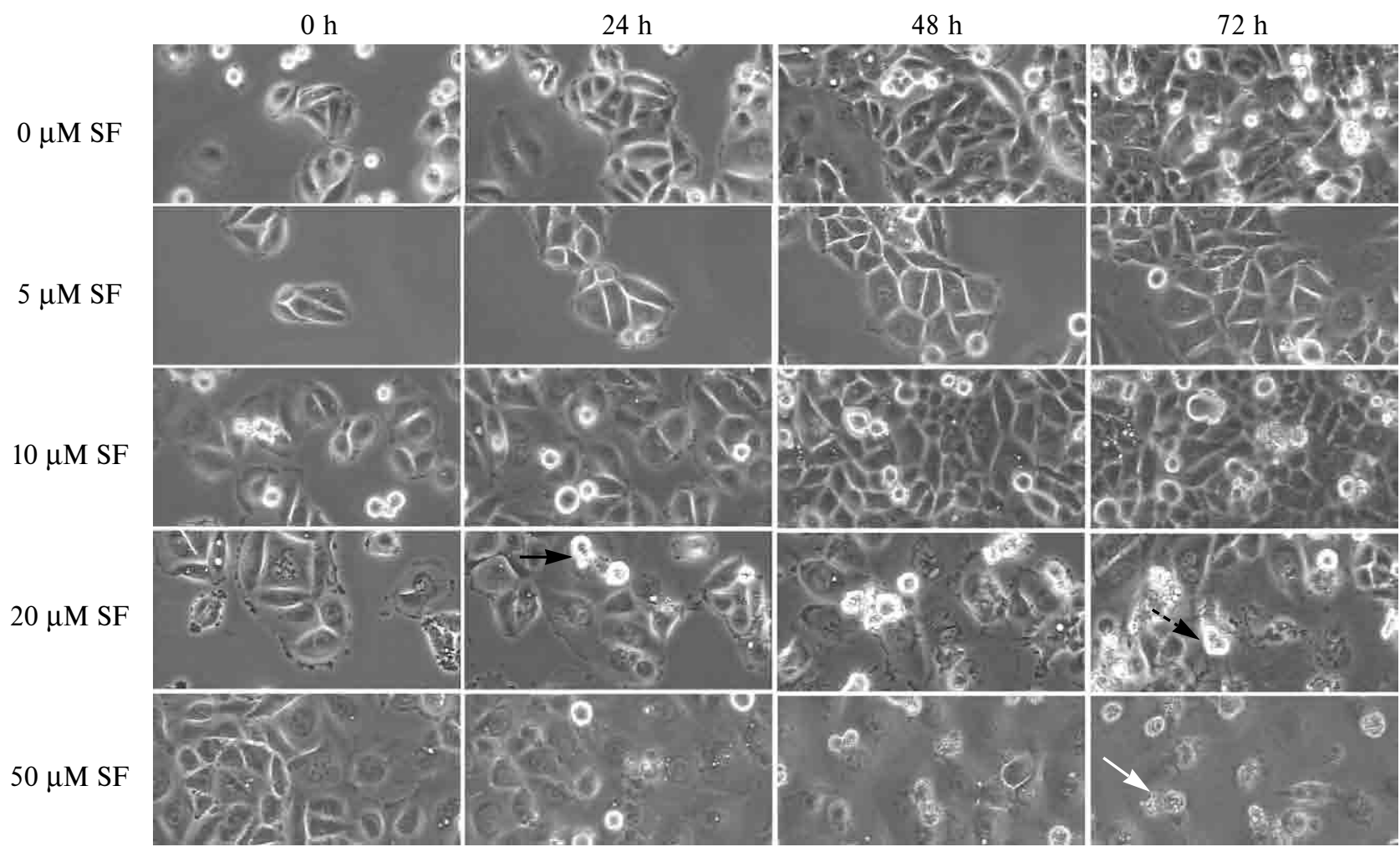

Fig. 2: Time- and concentration-dependent growth inhibition and morphological changes of SW620 cells after the exposure to sulforaphane (SF) at concentrations of $0-50 \mu \mathrm{M}$ for $72 \mathrm{~h}$. Black arrows indicate apoptotic cells with typical membrane blebbing (full arrow) and late apoptotic cells in terminal shrinkage (dashed arrow). White arrow denotes necrotic cell. Phase contrast (200x). Bar $15 \mu \mathrm{m}$. 
take assay and Coomasie brilliant blue assay (Fig. 1a,b). Based on Neutral red uptake assay effective cytotoxic concentrations of SF were as follows: $\mathrm{IC}_{50}=26 \mu \mathrm{M}$ at $24 \mathrm{~h}, \mathrm{IC}_{50}$ $=24.4 \mu \mathrm{M}$ at $48 \mathrm{~h}$ and $\mathrm{IC}_{50}=18 \mu \mathrm{M}$ at $72 \mathrm{~h}$. The results of both assays show a good correlation between SF-dependent loss of cell viability and decreasing cell proliferation during $72 \mathrm{~h}$ of treatment. This observation applies for all tested SF concentrations except the lowest $(5 \mu \mathrm{M})$ and the highest $(100 \mu \mathrm{M})$. Since cytotoxicity of the highest SF concentration $(100 \mu \mathrm{M})$ was very marked and occurring early in time, this concentration was omitted from further studies.

Time-lapse videomicroscopy records of SW620 cells exposed to different concentrations of SF up to $72 \mathrm{~h}$ demonstrated changes in cellular morphology; i.e. cell rounding followed by a loss of adherence with subsequent cell shrinkage and blebbing. While the lowest SF concentration of 5 $\mu \mathrm{M}$ did not cause any morphological alterations in SW620 cells (as demonstrated in Fig. 2, second row), higher con- centrations $(10,20,50 \mu \mathrm{M})$ had a significant effect on both cellular morphology as well as cell proliferation rate. Analyses of individual records proved that dynamics and timing of SFassociated inhibitory effects in SW620 cells differed among the higher SF concentrations (Fig. 2, third to fifth row).

\section{SF induces DNA damage in SW620 human colon cancer cells}

DNA damage and the resulting signaling in SF exposed SW620 cells was estimated by means of quantification of the amount of phophorylated histone H2A.X using western blot analysis. In Fig. 3, we demonstrated that all employed SF concentrations induced double strand breaks in DNA of SW620 cells as detected by phosphorylation of histone H2A.X at serine 139. This effect was dose-dependent ( $5 \mu \mathrm{M}$ SF $-130 \%$ of control versus $50 \mu \mathrm{M} \mathrm{SF}-290 \%$ of control as measured in relative intensity units) and occurred as early as at $24 \mathrm{~h}$ of exposure.

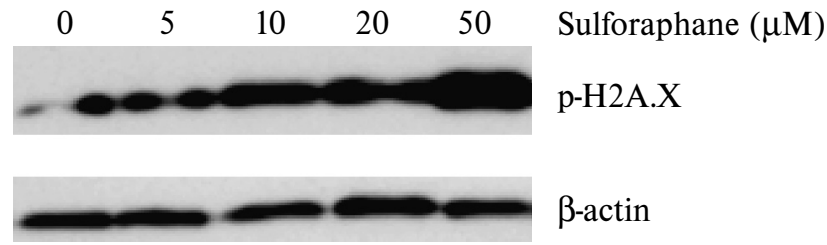

a)

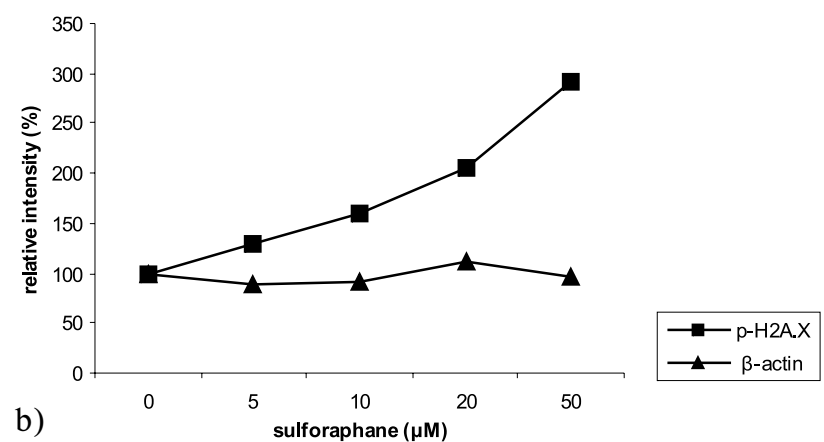

b)

Fig. 3: Levels of phosphorylated H2A.X (p-H2A.X) after 24 h treatment with various sulforaphane (SF) concentrations. SF-treated cells were harvested and p-H2A.X expression was determined by immunoblotting as described under Methods section. (a) Western blot of p-H2A.X and $\beta$-actin (control) (b) relative quantification of p-H2A.X and $\beta$-actin expression by GelQuant Ver 2.7 software.

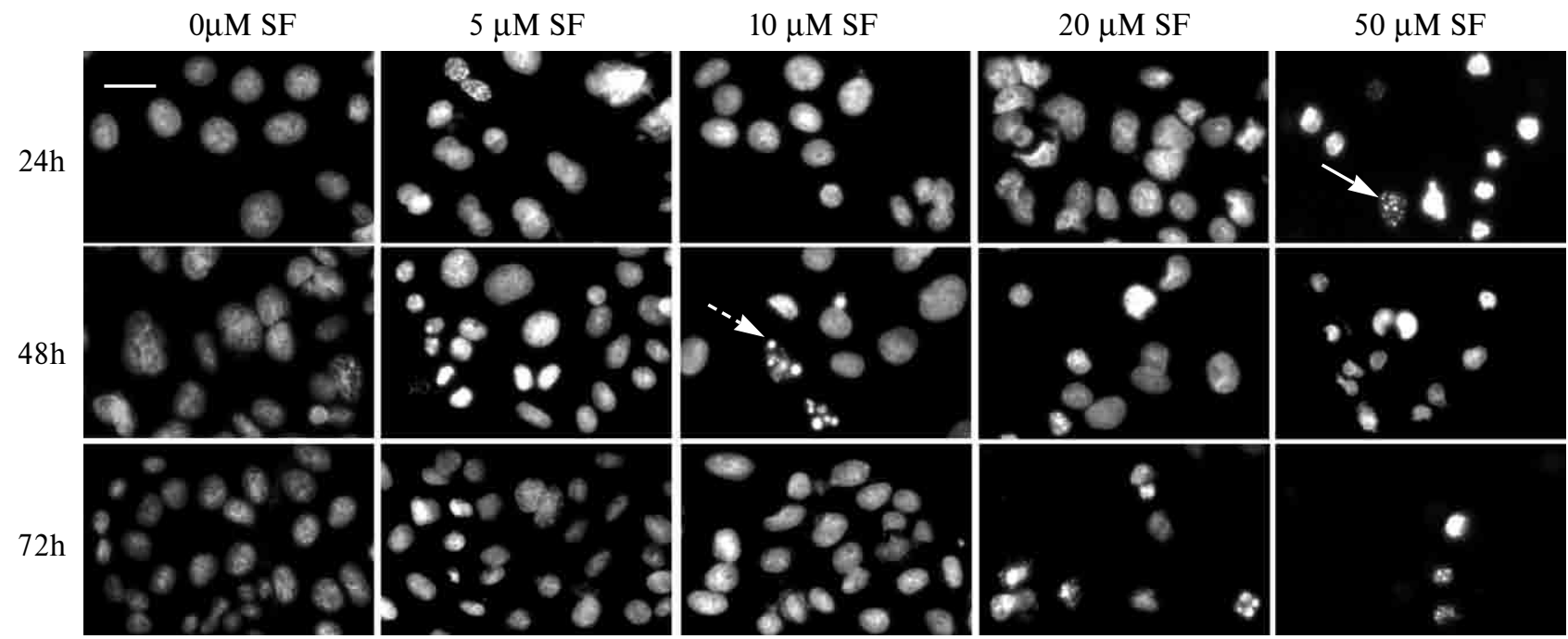

Fig. 4: Apoptotic changes in DAPI stained SW620 nuclei after treatment with sulforaphane (SF) during 72 h. White arrows indicate apoptotic nuclei with early chromatin clumping (full arrow) and late chromatin condensation (dahed arrow). Fluorescent microscopy (200x). Bar $10 \mu \mathrm{m}$. 


\section{SF activates apoptosis in SW620 human colon cancer cells}

Apoptosis in SW620 cells treated with SF was determined by nuclear staining with DAPI. As shown in Fig. 4, apoptotic nuclei with typical chromatin clumped morphology occurred in SF concentrations starting at $10 \mu \mathrm{M}$ during all followed treatment intervals. In order to confirm apoptosis in the employed model, caspase 3 activity upon the same treatment conditions was carried out. The results indicate that caspase 3 activity was significantly elevated in SF $20 \mu \mathrm{M}$ treated cells only. All other concentrations did not produce significantly different changes at all treatment intervals (Fig. 5).

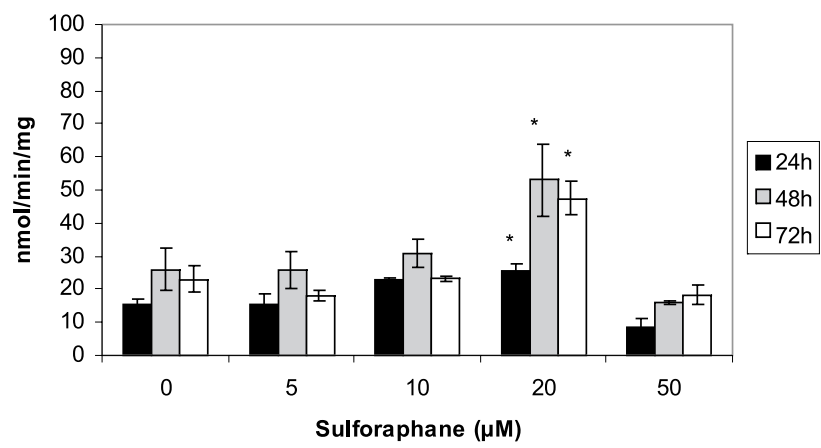

Fig. 5: Effect of sulforaphane (SF) on caspase 3 activity. SW620 cells were treated with SF concentrations (0-50 $\mu \mathrm{M}$ ) for up to $72 \mathrm{~h}$. Values represent the mean $\pm \mathrm{SD}$ of three independent experiments. ${ }^{*} \mathrm{P} \leq 0.05$, significantly different from control with one way-Anova test and Dunnett's post test for multiple comparisons.

\section{Discusion}

Isothiocyanates found in Brassica vegetables have been extensively studied as potential chemopreventive agents and their anti-cancer activities have been shown in several cancer models. Sulforaphane, one of the major isothiocyanates derived primarily from broccoli, has been described to inhibit the growth of various cancer cells and to induce apoptosis via numerous mechanisms of which only some are fully understood. Several published studies demonstrated cytotoxic potential of SF towards malignant colonic cells $(2,5)$; however, experimental evidence concerns only noninvasive and non-metastatic adenocarcinoma models. To determine whether SF is active in advanced stages of colon cancer too, we employed human colon cancer cell line SW620, which is derived from colon cancer metastases in the lymph node.

In the present study, we evaluated antiproliferative effects of SF on SW620 cells, using concentrations of this chemical up to $100 \mu \mathrm{M}$ during $72 \mathrm{~h}$. We chose this range of concentrations with respect to available pharmacokinetic evidence. Our data indicate that SF exerted an inhibitory effect on proliferation of SW620 cell line. Despite general agreement in the literature about antiproliferative effect of $\mathrm{SF}$ in colon cancer cells, individual published studies report varying $\mathrm{IC}_{50}$ values acquired after treatment with this chemical. The reason for these differences is either different sensitivities of the individual employed proliferation assays (i.e. Sulforhodamine B assay, MTT assay or MTS assay) or the unique genetic profile of used cells. Our own results agree with the former possibility as Neutral red uptake assay yielded $\mathrm{IC}_{50}=26 \mu \mathrm{M}$ while WST-1 assay produced $\mathrm{IC}_{50}=60 \mu \mathrm{M}$ (unpublished observation) during 24 $\mathrm{h}$ exposure to SF. In addition, it seems that a key role in the sensitivity of malignant colonocytes to SF might be at least partially played by the p53 cell status too. Supporting this notion, there was dramatically increased $\mathrm{IC}_{50}$ value in cells with mutated p53 (i.e. Caco-2 cells) in contrary to wild type p53 cells (HCT-116).

Although SF has been known to confer partial protection against DNA damage and, in particular single strand breaks in exposed cells, experimental evidence exists that SF induces oxidative stress which might be ultimately responsible for DNA damage. In order to explore this possibility we determined the levels of phosphorylated H2A.X histone in SF exposed cells during $24 \mathrm{~h}$. It is well documented that histone variant H2A.X is phosphorylated in response to DNA double-strand breaks. We found hyperphosphorylation of H2A.X occurring as early as after $24 \mathrm{~h}$ of treatment with all concentrations of SF. Furthermore, the amount of phosphorylated H2A.X in cells increased in a time- and dose-dependent manner. Thus our data clearly show that SF induces double-strand breaks in SW620 cells; whether it is due to its direct DNA interaction or via generation of reactive oxygen species (ROS) remains to be explored. Since there is no evidence that SF directly induces DNA breaks, it is reasonable to assume that SF-dependent oxidative stress is the main DNA-damaging mechanism.

Chromatin condensation is one of the most important nuclear events occurring during apoptosis. A typical pattern of apoptotic nuclei occurred after $24 \mathrm{~h}$ of $50 \mu \mathrm{M} \mathrm{SF}$ treatment. Moreover, after $48 \mathrm{~h}$ of SF treatment there were apoptotic nuclei in cultures treated with $10 \mu \mathrm{M}$ and $20 \mu \mathrm{M}$ SF too. Similar result have been published by GametPayrastre who observed apoptotic nuclei in HT-29 colon cancer cells exposed to $15 \mu \mathrm{M}$ SF for $48 \mathrm{~h}$.

The established hallmarks of apoptotic cell demise are the activation of executionary proteases (caspases) whose activities lead to the appearance of typical morphological features in dying cells. Caspase 3 is the main executionary protease and the involvement of this enzyme in SF treated cancer cells has been reported in several models, however, there is only one report about the activation of caspase 3 following the treatment with SF in human colon cancer models. We observed a slight elevation in caspase 3 activity in SF treated SW620 cells; still, this observation was limited only to $20 \mu \mathrm{M}$ SF. The absence of significantly increased caspase 3 activity after treatment with other SF concentrations may have several explanations. Firstly, the elevated ac- 
tivity of caspase 3 could be only transient, thus our chosen time intervals did not cover these putative activity peaks. Secondly, SF might induce caspase-independent apoptosis too as has been reported previously. Thirdly, SF may have a special "modulatory" effect to caspase 3 as only a low activation of the same caspase was noted in HT-29 cells after SF treatment. The final proof of the involved caspase 3 in SF induced cell death in SW620 cells, however, might be provided by more direct detection of activated caspase 3 and its targets using for instance immunocytochemical methods. We are planning to address this issue in our future experiments.

In summary, $\mathrm{SF}$ in a chosen concentration range of 10-50 $\mu \mathrm{M}$ inhibits the growth and proliferation of metastatic human colon cancer cells SW620 time- and dose-dependently. These effects may be attributed to SF-associated DNA damage and activation of cell death - apoptosis characterized by transient activation of caspase 3 and chromatin degradation. These results form the basis for further studies into specific molecular targets and mechanisms whereby SF exerts its potential chemopreventive activity in colon cancer cells.

\section{Acknowledgements}

This work has been supported by Ministry of Education Research Project MSM 0021620820.

\section{References}

1. Austin GL, Adair LS, Galanko JA, Martin CF, Satia JA, Sandler RS. A diet high in fruits and low in meats reduces the risk of colorectal adenomas. J Nutr 2007:137:999-1004.

2. Bonnesen C, Eggleston IM, Hayes JD. Dietary Indoles and isothiocyanates that are generated from cruciferous vegetables can both stimulate apoptosis and confer protection against DNA damage in human colon cell lines. Cancer Res 2001;61:6120-30.

3. Cohen JH, Kristal AR, Stanford JL. Fruit and vegetable intakes and prostate cancer risk. J Natl Cancer Inst 2000;92:61-68.

4. Fernandez-Capetillo O, Lee A, Nussenzweig M, Nussenzweig A. H2AX: the histone guardian of the genome. DNA Repair 2004;3:959-67.
5. Gamet-Payrastre L, Li P, Lumeau S, Cassar G, Dupont MA, Chevolleau S, Gasc $\mathrm{N}$, Tulliez J, Terce F. Sulforaphane, a naturally occurring isothiocyanate, induces cell cycle arrest and apoptosis in HT29 human colon cancer cells. Cancer Res 2000;60:1426-33.

6. Gasper AV, Al-janobi A, Smith JA, Bacon JR, Fortun P, Atherton C, Taylor MA, Hawkey CJ, Barrett DA, Mithen RF. Glutathione S-transferase M1 polymorphism and metabolism of sulforaphane from standard and high-glucosinolate broccoli. Am J Clin Nutr 2005;82:1283-91.

7. Giovannucci E, Rimm EB, Liu Y, Stampfer MJ, Willett WC. A prospective study of cruciferous vegetables and prostate cancer. Cancer Epidemiol Biomarkers Prev 2003;12:1403-09.

8. Gonzalez CA, Riboli E. Diet and cancer prevention: Where we are, where we are going. Nutr Cancer 2006;56:225-31.

9. Jakubíková J, Sedlák J, Mithen R, Bao Y. Role of PI3K/Akt and MEK/ERK sig naling pathways in sulforaphane- and erucin-induced phase II enzymes and MRP2 transcription, G2/M arrest and cell death in Caco-2 cells. Biochem Pharmacol 2005;69:1543-52

10. Jeong W-S, Kim I-W, Hu R, Kong A-NT. Modulatory Properties of various natural chemopreventive agents on the activation of NF-KB signaling pathway. Pharm Res 2004;21:661-70.

11. Karmakar S, Weinberg MS, Banik NL, Patel SJ, Ray SK. Activation of multiple molecular mechanisms for apoptosis in human malignant glioblastoma T98G and U87MG cells treated with sulforaphane. Neuroscience 2006;141: $1265-80$

12. Pappa G, Lichtenberg M, Iori R, Barillari J, Bartsch H, Gerhauser C. Comparison of growth inhibition profiles and mechanisms of apoptosis induction in human colon cancer cell lines by isothiocyanates and indoles from Brassicaceae. Mutat Res 2006;599:76-87.

13. Payen L, Courtois A, Loewert M, Guillouzo A, Fardel O. Reactive oxygen species-related induction of multidrug resistance-associated protein 2 expression in primary hepatocytes exposed to sulforaphane. Biochem Biophys Res Commun 2001;282:257-63.

14. Pledgie-Tracy A, Sobolewski MD, Davidson NE. Sulforaphane induces cell typespecific apoptosis in human breast cancer cell lines. Mol Cancer Ther 2007; 6:1013-21.

15. Singh SV, Herman-Antosiewicz A, Singh AV, Lew KL, Srivastava SK, Kamath R, Brown KD, Zhang L, Baskaran R. Sulforaphane-induced G2/M phase cell cycle arrest involves checkpoint kinase 2-mediated phosphorylation of cell division cycle 25C. J Biol Chem 2004;279:25813-22.

16. Traka M, Gasper AV, Smith JA, Hawkey CJ, Bao Y, Mithen RF. Transcriptome analysis of human colon Caco-2 cells exposed to sulforaphane. J Nutr 2005; 135:1865-72.

17. Verhoeven DTH, Verhagen H, Goldbohm RA, van den Brandt PA, van Poppel G A review of mechanisms underlying anticarcinogenicity by brassica vegetables. Chem Biol Interact 1997:103:79-129.

18. Yeh C-T, Yen G-C. Effect of sulforaphane on metallothionein expression and induction of apoptosis in human hepatoma HepG2 cells. Carcinogenesis 2005;26:2138-48

19. Zhang Y, Li J, Tang L. Cancer-preventive isothiocyanates: dichotomous modulators of oxidative stress. Free Radic Biol Med 2005;38:70-77.

\section{Corresponding author:}

Mgr. Hana Andělová, Charles University in Prague, Faculty of Medicine in Hradec Králové, Department of Medical Biology and Genetics, Šimkova 870, 50038 Hradec Králové, Czech Republic, e-mail: andelova@sujchbo.cz 